\title{
Prevalence of celiac disease predisposing genotypes, including HLA-DQ2.2 variant, in Brazilian children
}

\author{
Nicole SELLESKI ${ }^{1,2}$, Lucas Malta ALMEIDA ${ }^{1}$, Fernanda Coutinho de ALMEIDA ${ }^{1,3}$, Claudia Beatriz PRATESI ${ }^{1,2}$, \\ Yanna Karla de Medeiros NÓBREGA ${ }^{1,4}$ and Lenora GANDOLFI ${ }^{1,2}$
}

\begin{abstract}
Background - Celiac disease is an autoimmune enteropathy triggered by the ingestion of gluten in genetically susceptible individuals. Almost all celiac patients carry immune recognition genes coding for HLA-DQ2.5 and DQ8 heterodimers. Over the last few years, great importance has been given to HLA-DQ2.2 as probable predisposing variant, although controversies still exist regarding its relevance. Objective - The aim of our study was to determine the possible existence of an association between HLA-DQ2.2 and celiac disease in Brazilian children by analyzing the prevalence of the predisposing variants for celiac disease in a representative group of children of a population in which this determination is still missing. Methods HLA-DQ typing was performed in samples from a group of celiac $(\mathrm{n}=100)$ and non-celiac children $(\mathrm{n}=110)$. All samples were tested for the presence of the following variants: $D Q A 1^{*} 05-D Q B 1^{*} 02$ (DQ2.5), $D Q A 1^{*} 03-D Q B 1^{*} 03: 02$ (DQ8) and $D Q A 1 * 02: 01-D Q B 1^{*} 02: 02$ (DQ2.2). Fisher`s exact test was used for statistical analysis. Results - In the group of 100 celiac children, 78 (78\%) were positive for DQ2, 13 (13\%) were DQ2/DQ8 and $6(6 \%)$ were DQ8 positives. The HLA-DQ pattern in the 110 non-celiac children was as follows: positive for DQ2 in $33(29.9 \%)$ samples, in $2(1.8 \%)$ was positive for DQ2/DQ8 and in $15(13.6 \%)$ was positive for DQ8. We found significant differences between the distribution of some but not all of the analyzed alleles when comparing celiac and non-celiac children. Conclusion - The genotyping of celiac disease HLA-DQ predisposing alleles showed similarities with HLA-DQ patterns found in both European and non-European populations, which may be a reflection of the miscegenation, which gave origin to the current Brazilian population. No significant association was found between DQ2.2 variant and celiac disease in the studied population. HEADINGS - Celiac disease, genetics. Prevalence. Genotyping techniques. HLA-DQ antigens.
\end{abstract}

\section{INTRODUCTION}

Celiac disease (CD) is a common autoimmune enteropathy (prevalence estimated at $1 \%$ in Caucasian population) $)^{(1)}$ triggered by the ingestion of gluten in genetically susceptible individuals. Gluten is a protein component in wheat (a staple food for most populations in the world) and other cereals like rye and barley ${ }^{(2)}$.

During the pathogenesis of celiac disease, a T-cell mediated response to dietary gluten causes the overproduction of inflammatory cytokines, which contribute to the damage of the intestinal mucosa. A B-cell mediated response is also activated, with an increased production of IgA anti-tissue transglutaminase antibodies (IgAtTG $)^{(3)}$. Anti-IgA-tTG antibodies, together with anti-endomysium antibodies (IgA-EMA) can be detected in patients' sera, and are the first step in the diagnosis of $\mathrm{CD}^{(4)}$.

An outstanding feature of CD is that almost all affected individuals carry immune recognition genes coding for HLA-DQ2.5 and/or DQ8 heterodimers, which facilitate $\mathrm{CD}^{+} \mathrm{T}$-cell recognition of specific gluten-derived peptides ${ }^{(3)}$. These heterodimers are encoded by two sets of HLA alleles: $D Q A 1 * 05-D Q B 1 * 02$ (DQ2.5), $D Q A 1^{*} 03-D Q B 1^{*} 03: 02$ (DQ8) ${ }^{(3)}$. Therefore, during a CD diagnostic workup, the absence of these specific DQA1 and DQB1 alleles has a near perfect negative predictive value ${ }^{(5)}$. However, there are still some patients that don't carry neither of these predisposing variants. In an attempt to describe the genetic bases of the disease on those patients, some authors found significance in the association between celiac disease and HLA-DQ2.2 $\left(D Q A 1^{*} 02: 01-D Q B 1^{*} 02: 02\right)^{(6)}$ but they are still a lot of controversies regarding the role of this heterodimer.

Many studies reflect the importance of genetic factors in the pathogenesis of $\mathrm{CD}^{(7)}$. A recent work from Anderson et al. (2013) suggested that a combination of human leukocyte antigen (HLA) typing and confirmatory serology could decrease the number of unnecessary endoscopies as well as the number of false negatives and/or positive diagnoses. For this to be useful, we should know the prevalence of these genotypes in the area of interest as they proved to be slightly different between populations around the world ${ }^{(7-9)}$. The aim of our work was to study the association between HLA-DQ2.2 and celiac disease in Brazilian children by analyzing the prevalence of the predisposing variants for celiac disease in a population that still lacks this information.

Declared conflict of interest of all authors: none

Disclosure of funding: no funding received

${ }^{1}$ Laboratório Interdisciplinar de Biociências, Laboratório de Pesquisa em Doença Celíaca, Faculdade de Medicina, Universidade de Brasília, Brasília, DF, Brasil· 2 Programa de Pós-Graduação em Ciências da Saúde. Faculdade de Ciências da Saúde, Universidade de Brasília, Brasília, DF Brasil· 3 Programa de Pós-Graduação em Ciências Médicas, Faculdade de Ciências Médicas, Universidade de Brasília, DF, Brasil; ${ }^{4}$ Programa de Pós-Graduação em Ciências Farmacêuticas, Faculdade de Ciências da Saúde, Universidade de Brasília, DF, Brasil.

Correspondence: Nicole Selleski. Laboratório Interdisciplinar de Biociências, Laboratório de Pesquisa em Doença Celíaca, Faculdade de Medicina da Universidade de Brasília. Campus Universitário Darcy Ribeiro. Asa Norte - CEP: 70910-900. Brasília, DF, Brasil. Email: selleskinicole@gmail.com 


\section{METHODS}

\section{Study population and data collection}

This research complied with the principles of the latest Declaration of Helsinki ${ }^{(10)}$ and was approved by the Ethics Committee of the University of Brasilia, School of Health Sciences, protocol CEP-FS 132/08. After extensive explanation on purpose and procedures involved in the research a written informed consent was obtained from the children's parents or caregivers.

The study population consisted in a group of celiac and nonceliac children from the city of Brasilia, Brazil. Brasilia, from the viewpoint of population studies, has the advantage of being considered representative of the Brazilian population at large given its past-history of high rate of migratory waves from a variety of Brazilian regions.

Whole blood (approximately $5 \mathrm{~mL}$ ) was collected by venipuncture from children attending the outpatient clinic of the Celiac Disease Research Center of the University Hospital of Brasilia. The groups were composed by 100 celiac children (41 male, 59 female; mean age: 6.9 yrs, median 8 yrs, age range: 1 to $15 \mathrm{yrs}$ ), and 110 presumably healthy non-celiac children ( 47 males, 63 females; mean age: $7 \mathrm{yrs}$, median $8 \mathrm{yrs}$, age range: 1 to $15 \mathrm{yrs}$ ). Non-celiac children underwent IgA-tTG and IgA-EMA assays to exclude CD, all yielding negative results. Celiac children had already been diagnosed following the European Society of Pediatric Gastroenterology, Hepatology and Nutrition (ESPGHAN) criteria $^{(4)}$.

\section{HLA genotyping}

DNA extraction was performed in all samples using Illustra ${ }^{\mathrm{TM}}$ Blood genomic Prep Mini Spin Kit (Healthcare, Buckinghamshire, UK), according to the manufacturer's instructions. The procedure for the determination of CD-predisposing HLA genotypes was similar for both celiac and non-celiac samples. $D Q A 1 * 05-D Q B 1^{*} 02$ (DQ2.5) and $D Q A 1 * 03-D Q B 1 * 03: 02$ (DQ8) amplifications were performed using qPCR technique (Step One Real Time PCR System; Applied Biosystems, Life Technologies ${ }^{\mathrm{TM}}$, Carlsbad, CA, USA). This procedure is part of our screening routine in view of its simplicity and accessibility. Typing of DQA $1 * 05, \mathrm{DQB} 1 * 02$ and
DQA1*03 were performed as described by Selleski et al. (2015). Amplification of DQB1*03:02 allele and human growth hormone gene $(\mathrm{HGH})$, that was used as internal control, were performed according to Profaizer et al. (2011).

Positive $D Q B 1^{*} 02$ samples were further tested for the presence of the DQ2.2 variant $\left(D Q A 1^{*} 02: 01-D Q B 1 * 02: 02\right)$ using DQCD TypingKitPlus (BioDiagene, Palermo, Italy) according to the manufacturer's recommendations.

\section{Statistical analysis}

Frequencies of both groups were compared by using Fisher's exact test. Results were considered significant when $P<0.05$. Statistical analysis was performed using GraphPad Prism Version 5.

\section{RESULTS}

From a total of 100 celiac children, $51(51 \%)$ tested positive for DQ2.5 only; 22 (22\%) for DQ2.5/DQ2.2; $5(5 \%)$ for DQ2.2 only; $7(7 \%)$ for DQ2.5/DQ8; 6 (6\%) for DQ2.2/DQ8; 6 (6\%) for DQ8 only; $1(1 \%)$ was $D Q B 1^{*} 02$ positive; $1(1 \%)$ showed low risk predisposing alleles and $1(1 \%)$ tested negative for all of the searched alleles.

All 110 non-celiac children tested negative for the performed serologic tests. Genetic analysis showed that $16(14.5 \%)$ were DQ2.5 only, $4(3.6 \%)$ were DQ2.5/DQ2.2, $13(11.8 \%)$ were DQ2.2 only, $1(0.9 \%)$ DQ2.5/DQ8, $1(0.9 \%)$ DQ2.2/DQ8, $15(13.6 \%)$ DQ8 only, 2 (1.8\%) were $D Q B I^{*} 02$ positives, $29(26.4 \%)$ showed low risk predisposing alleles and $29(26.4 \%)$ tested negative for all of the searched alleles.

TABLE 1 shows the most relevant results and details of the statistical analysis performed using Fisher's exact test.

\section{DISCUSSION}

Over the last years, great importance has been given to HLA genotyping in the prediction and prognosis of many autoimmune diseases including celiac disease. However, due to their heterogeneous distribution in different populations around the world, genotypes' prevalence must be first characterized for the local population to be able to compare it to at-risk subjects.

TABLE 1. Prevalence of $C D$ predisposing genotypes and statistical analyses

\begin{tabular}{|c|c|c|c|c|c|c|c|c|}
\hline Genotypes & Variant & \multicolumn{3}{|c|}{ Celiac children $(n=100)$} & \multicolumn{3}{|c|}{ Non-celiac children $(n=110)$} & $P$ value \\
\hline \multirow{3}{*}{ DQ2 } & DQ2.5 & 51 & 51 & \multirow{3}{*}{78} & 16 & 14.5 & \multirow{3}{*}{29.9} & $<0.0001$ \\
\hline & DQ2.2 & 5 & 5 & & 13 & 11.8 & & 0.0888 \\
\hline & DQ2.5/DQ2.2 & 22 & 22 & & 4 & 3.6 & & $<0.0001$ \\
\hline DQ8 & & 6 & 6 & 6 & 15 & 13.6 & 13.6 & 0.0706 \\
\hline \multirow{2}{*}{ DQ2/DQ8 } & DQ2.5/DQ8 & 7 & 7 & \multirow{2}{*}{13} & 1 & 0.9 & \multirow{2}{*}{1.8} & 0.0288 \\
\hline & DQ2.2/DQ8 & 6 & 6 & & 1 & 0.9 & & 0.0554 \\
\hline
\end{tabular}


The inclusion of HLA-DQ2.2 as a predisposing variant for celiac disease remains under discussion with it being significant for some but not all studied populations ${ }^{(6-13)}$.

Although about $30 \%-40 \%$ of the general population carry HLADQ2 and/or DQ8 without developing CD, these alleles are absent in less than $0.5 \%$ of CD patients ${ }^{(14)}$. HLA typing is considered an excellent tool to be used before performing more invasive tests like endoscopy, when serology is ambiguous in subjects being investigated for $\mathrm{CD}^{(4-8)}$. Additionally, in individuals considered at high risk for $\mathrm{CD}$ as first-degree relatives, patients with immunoglobulin A deficiency, other autoimmune diseases or with Down, Turner or Williams syndromes, the HLA typing is used to exclude those in which these alleles are absent from further investigation. The absence of predisposing alleles spares individuals of unnecessary serial serological testing while confirmation of their presence reflects an increased likelihood of developing CD. Thereby, in individuals disclosing HLA predisposing alleles on genetic testing periodic screening for autoantibodies against IgA tTG and IgA EMA should be considered to avoid non-detection of subclinical or silent forms of the disease ${ }^{(5)}$.

As already stated above, the prevalence of $C D$ predisposing $D Q$ alleles was already described in many countries around the word and it showed some differences between them ${ }^{(3)}$. In this work, we evaluated the presence of these alleles in both celiac and non-celiac children from a population that still lacked this information, the Brazilian population. As expected, we found many significant differences in the distribution of the analyzed alleles which supports the existence of strong genetic basis in $\mathrm{CD}^{(3,4)}$ (TABLE 1). However, no significant differences were found between groups when analyzing HLA-DQ8 genotype. While it might be attributed to the sample size, an increased prevalence of this variant was already reported in the general population of another South-American country, Chile, which showed strong Amerindian ancestry ${ }^{(15)}$. In addition, we included in our work HLA-DQ2.2 as a predisposing variant whereby several celiac individuals that initially tested positive for DQ8 only $(\mathrm{n}=12)$ were actually DQ2.2/DQ8 $(\mathrm{n}=6)$. The total prevalence of predisposing variants in celiac and non-celiac individuals found in our study was similar to the ones showed in other studies from Italy and Libya ${ }^{(16,17)}$. (TABLE 2).

The extremely high percentage of patients with CD carrying either HLA-DQ2.5 or HLA-DQ8 has led to the common practice of excluding CD in patients without these HLA types ${ }^{(4)}$.
However, other reports describe patients with $\mathrm{CD}$ who lack both HLA-DQ2.5 and -DQ8, making the validity of this strong negative predictive value questionable ${ }^{(13-18)}$. Previous studies already showed that a great proportion of DQ2.5 and DQ8 negative CD patients were positives for the DQ2.2 variant ${ }^{(6-18)}$ concluding that DQ2.2 should be considered as a risk variant for celiac disease. Other studies also gave details on the probable molecular role of the heterodimer coded by this variants ${ }^{(18,19)}$. However, we found no significant difference between celiac and non-celiac children, suggesting that this variant is not relevant for the population under analysis.

Although our study had some limitations regarding the sample size; presently, further studies are underway in our laboratory to overcome these drawbacks, including a broader population both in sample size and patient's age range.

\section{CONCLUSION}

The genotyping of celiac disease HLA-DQ predisposing alleles showed similarities with both European and non-European patterns, which may be a reflection of the miscegenation that originated the actual Brazilian population. No significant association was found between DQ2.2 variant and celiac disease in the studied population.

\section{ACKNOWLEDGEMENT}

We would like to thank Coordenação de Aperfeiçoamento de Pessoal de Nivel Superior (CAPES), and Fundação de Apoio ao Desenvolvimento Científico e Tecnológico do Hospital Universitário de Brasília for their financial support.

\section{Authors' contributions}

Nóbrega YKM, Pratesi CB and Gandolfi L conceived the study design and revised the manuscript; Almeida LM, Almeida FC and Selleski N performed HLA genotyping of all celiac and non-celiac children; Selleski $\mathrm{N}$ performed the statistical analysis and wrote the manuscript, Almeida LM, Almeida FC and Selleski N performed the controls anti-transglutaminase and anti-endomysium tests, Gandolfi L collected blood and serum samples from patients and controls and organized all their clinical data.

TABLE 2. Comparison of prevalence (\%) of CD predisposing HLA-DQ genotypes between different populations

\begin{tabular}{|c|c|c|c|c|c|c|}
\hline Genotype & $\mathrm{CD}$ & Non-CD & $\mathrm{CD}$ & Non-CD & $\mathrm{CD}$ & Non-CD \\
\hline DQ2 & 78 & 29.9 & 78.2 & 21.6 & 84 & 30.8 \\
\hline DQ8 & 6 & 13.6 & 10.3 & 7.2 & 13 & 16.7 \\
\hline Total & 97 & 45.3 & 91 & 29 & 97 & 50.7 \\
\hline
\end{tabular}

* Data from Megiorni et al. ${ }^{(16)}$. ** Data from Alarida et al..$^{(17)}$. 
Selleski N, Almeida LMA, Almeida FC, Pratesi CB, Nóbrega YKM, Gandolfi L. Prevalência de genótipos predisponentes para doença celíaca, incluindo HLA-DQ2.2, em crianças brasileiras. Arq Gastroenterol. 2018;55(1):82-5.

RESUMO - Contexto - A doença celíaca é uma enteropatia autoimune, desencadeada pela ingestão do glúten em indivíduos geneticamente predispostos. Quase todos os pacientes celíacos possuem genes que codificam os heterodímeros HLA-DQ2.5 e DQ8. Nos últimos anos, mesmo com algumas controvérsias a respeito, tem se dado grande importância ao HLA-DQ2.2 como outra provável variante predisponente para doença celíaca. Objetivo - O objetivo do nosso trabalho foi determinar a provável associação entre HLA-DQ2.2 e a doença celíaca em crianças brasileiras, mediante a análise da prevalência das variantes predisponentes para doença celíaca em um grupo representativo desta população que ainda carece de dita informação. Métodos - A genotipagem das variantes HLA-DQ foi realizada em populações de crianças celíacas ( $\mathrm{n}=100)$ e não celíacas ( $\mathrm{n}=110)$. A presença das seguintes variantes foi testada em todas as amostras: $D Q A 1 * 05-D Q B 1 * 02$ (DQ2.5), DQA1*03-DQB1*03:02 (DQ8) e DQA1*02:01-DQB1*02:02 (DQ2.2). A análise estatística foi realizada utilizando o teste exato de Fisher. Resultados - No grupo de 100 crianças celíacas, 78 ( $78 \%$ ) foram positivas para DQ2, $13(13 \%)$ para DQ2/DQ8 e $6(6 \%)$ foram DQ8 positivas. O padrão de variantes predisponentes no grupo de 110 crianças não celíacas foi: $33(29.9 \%)$ amostras positivas para DQ2, $2(1.8 \%)$ DQ2/DQ8 positivas e $15(13.6 \%)$ DQ8 positivas. Quando as prevalências de ambos grupos foram compradas, foram achadas diferenças significativas entre algumas, mas não todas as variantes predisponentes. Conclusão - A genotipagem das variantes HLA-DQ predisponentes para doença celíaca mostrou um padrão similar ao achado em populações europeias e não-europeias, o qual pode ser resultado da miscigenação que deu origem à população brasileira atual. Nosso trabalho não mostrou associação significativa entre a variante DQ2.2 e a doença celíaca na população estudada.

DESCRITORES - Doença celíaca, genética. Prevalência. Técnicas de genotipagem. Antígenos HLA-DQ.

\section{REFERENCES}

1. Green PHR, Cellier C. Celiac Disease. N Engl J Med. 2007;357:1731-43.

2. Fasano A, Catassi C. Current approaches to diagnosis and treatment of celiac disease: An evolving spectrum. Gastroenterology. 2001;120:636-51.

3. Abadie V, Sollid LM, Barreiro LB, Jabri B. Integration of genetic and immunological insights into a model of celiac disease pathogenesis. Annu Rev Immunol. 2011;29:493-525

4. Husby S, Koletzko S, Korponay-Szabó IR, Mearin ML, Phillips A, Shamir R, et al. European Society for Pediatric Gastroenterology, Hepatology, and Nutrition guidelines for the diagnosis of coeliac disease. J Pediatr Gastroenterol Nutr. 2012;54:136-60.

5. Wolters VM, Wijmenga C. Genetic background of celiac disease and its clinical implications. Am J Gastroenterol. 2008;103:190-5.

6. Mubarak A, Spierings E, Wolters V, van Hoogstraten I, Kneepkens CMF, Houwen R. Human leukocyte antigen DQ2.2 and celiac disease. J Pediatr Gastroenterol Nutr. 2013;56:428-30.

7. Gujral N, Freeman HJ, Thomson ABR. Celiac disease: prevalence, diagnosis, pathogenesis and treatment. World J Gastroenterol. 2012;18:6036-59.

8. Anderson RP, Henry MJ, Taylor R, Duncan EL, Danoy P, Costa MJ, et al. A novel serogenetic approach determines the community prevalence of celiac disease and informs improved diagnostic pathways. BMC Med. 2013;11:188.

9. Catassi C, Rätsch IM, Gandolfi L, Pratesi R, Fabiani E, El Asmar R, et al. Why is coeliac disease endemic in the people of the Sahara? Lancet. 1999;354:647-8.

10. WMA Declaration of Helsinki 2013. [Internet]. Available from: https://www. wma.net/wp-content/uploads/2016/11/DoH-Oct2013-JAMA.pdf
11. Selleski N, Almeida LM, Almeida FC De, Gandolfi L, Pratesi R, Nóbrega YKDM. Simplifying celiac disease predisposing HLA-DQ alleles determination by the real time PCR method. Arq Gastroenterol. 2015;52:143-6.

12. Profaizer T, Eckels D, Delgado JC. Celiac disease and HLA typing using real-time PCR with melting curve analysis. Tissue Antigens. 2011;78:31-7.

13. Karell K, Louka AS, Moodie SJ, Ascher H, Clot F, Greco L, et al. Hla types in celiac disease patients not carrying the DQA $1 * 05-\mathrm{DQB} 1 * 02(\mathrm{DQ} 2)$ heterodimer: results from the european genetics cluster on celiac disease. Hum Immunol. 2003;64:469-77.

14. Schuppan D, Junker Y, Barisani D. Celiac disease: from pathogenesis to novel therapies. Gastroenterology 2009;137:1912-33.

15. Pérez-Bravo F, Araya M, Mondragón A, Ríos G, Alarcón T, Roessler JL, et al. Genetic differences in HLA-DQA1* and DQB1* allelic distributions between celiac and control children in Santiago, Chile. Hum Immunol. 1999;60:262-7.

16. Megiorni F, Mora B, Bonamico M, Barbato M, Nenna R, Maiella G, et al. HLA-DQ and risk gradient for celiac disease. Hum Immunol. 2009;70:55-9.

17. Alarida K, Harown J, Di Pierro MR, Drago S, Catassi C. HLA-DQ2 and -DQ8 genotypes in celiac and healthy Libyan children. Dig Liver Dis. 2010;42:425-7.

18. Harmon GS, Lebeck LK, Weidner N. Gluten-dependent enteropathy and atypical human leukocyte antigen alleles. Hum Pathol. 2011;42:1112-6.

19. Fallang L-E, Bergseng E, Hotta K, Berg-Larsen A, Kim C-Y, Sollid LM. Differences in the risk of celiac disease associated with HLA-DQ2.5 or HLADQ2.2 are related to sustained gluten antigen presentation. Nat Immunol. 2009; 10:1096-101. 